\title{
Hoax and Journalism in Media Literacy Approach
}

\author{
Abdul Jalil Hermawan* \\ Faculty of Social and Political Studies \\ Universitas Swadaya Gunung Jati \\ Cirebon, Indonesia \\ *abdjaltea@yahoo.com
}

\begin{abstract}
The contents of journalism have rules when a news to broadcast. At least nine elements journalist was be border it. If journalism is required to uphold these nine principles, so should social media. The controller by individuals itself. Hoaxes, slanders, and expressions of hatred are increasingly out of control. Public ethics on social media do not seem to apply so that people easily attack, judge, or curse with harsh words. The research to describe Hoaxes and Journalism is different term. In the realm of journalism, before disseminating information there are signs that must be fulfilled. There are several layers that must be passed when news can be disseminated. The role of the gatekeeper in the mass media has an important role. The gatekeeper here serves to select every news content starting from, pictures, grammar, logic and socio-cultural impact of news. Editors, editor, language editor to editor in chief are part of the gatekeepers. In the aftermath of the rampant waste of information on social media, people tend to see reality based on their own glasses. The reality carried by a group of people is believed and distorts the meaning and severity of what is believed is then fought for. The spread of Hoax has also opened up real social spaces.
\end{abstract}

Keywords: Hoax, journalism, verification, news

\section{INTRODUCTION}

The mandate of Indonesian President Joko Widodo on the national press day in Ambon on February 9, 2017 was so clear. Mainstream media don't lose out to hoax news that is scattered on social media. The mandate shows President is so disturbed by slanderous news, hate speech that are now seemingly unstoppable into the private spaces of citizens. The intensity of unclear news which is without verification increasingly day to day. This condition is the clearest challenge for mainstream journalism to decoy and give society a pure information without hoax. In journalism approach news is has been framed with various kinds of ethics, hoax delivered often ignores ethics and even pretends to ignite hostility and anger.

There are four negative impacts of the spreading hoax. Wasting time, issues decoy, public fraud and the trigger of social panic. Cmsconnect says the consumption of hoax can be losses of productivity. The decreased of productivity to have impact to reduce income. Secondly is the decoy of issues. On social media or the internet especially internet criminals or commonly called cyber-crime, hoaxes are usually used as facilitators of their crime on the internet or on social media. For example, cyber criminals will send a hoax that contains a system vulnerability in internet services such as Gmail and
Ymail. Then, the criminals will send a link in the form of a link to the users or users who contain suggestions to click the link so that user accounts will be protected from Gmail or Ymail system vulnerabilities. In fact, in reality the link is a virus that can hijack the Gmail and Ymail of the users we commonly call hacking.

Thirdly is public fraud. This type of fraud usually aims to attract the sympathy of people who believe in the hoax. Then when it is recommended to donate some money and strangely there are those who want to donate the money without wanting to think deeper or in detail whether the news is proven to be true or false. Many people are finally deceived by the hoax and in the end have already sent a very large amount of money. One example of the case as quoted from indolinear.com a few month ago there is a message at WhatsApp the containing recruitment the national CPNS registration. After the news of the hoax was spread, the government finally clarified that the government did not open CPNS registration at time.

And the last one is a trigger for panic public. Usually fake news that stimulates public panic, and the news contains about acts of violence or a certain disaster. One example is the hoax about the accidental loss of the Garuda Indonesia flight Jakarta - Palu a time ago. This hoax spreads so quickly that the mass media and online media have to clarify the news so that people do not panic or believe in the hoax.

\section{METHOD}

This research is carry out in Cirebon City West Java. Especially at journalism community when they take out or deliver a news. Why Journalists? Caused they are one of the Mass circle for spreading a news. Journalist preparing and showing a news. The research method used qualitative approach. Qualitative research is a scientific method of observation to gather non-numerical data. This type of research "refers to the meanings, concepts, definitions, characteristics, metaphors, symbols, and description of things" and not to their "counts or measures".

As a researcher, digging many information from source and many literatures. To find how hoax can be desperate community and destroy a social values. There are three of local journalists and two of local citizen. 


\section{RESUlTS AND DISCUSSION}

The sciences of journalism have many rules when news should be spreading away. And there signs must be fulfilled. There are several layers that must be passed when a news can be disseminated or spread. The role of gatekeeper in the mass media has an important role. The gatekeepers have ability to select every news content starting from, pictures, grammar, logic and socio-cultural until impact of a news. Editor, language of editor to editor in chief are part of the gatekeepers [1].

Besides gatekeepers, Bill Kovack and Thomas Rosenstiel in their book The Elements of Journalism What News people Should Know and The Public Should Expect write at least there are nine elements of journalism that must be obeyed before the news is spread. Journalism must be find and convey the truth is the first element. This element is probably no define what can be only one reference. Because the truth from the view of Muslims is not necessarily true from the Christian community. But in this context functional truth is not philosophical truth. The public wants to know the price increase. Stock fluctuations. Natural disasters and so on. In the context of hoax the role of the gatekeeper is completely invisible. If there is a figure gatekeeper will direct only the interests of the group [2].

But knowing right or wrong is not enough. Kovach and Rosenstiel explained the second element by asking, "To whom should a journalist faced his loyalty? At the company? To the reader? Or to the public? Ideally journalism must respect the community. Not to media owners, not to advertisers and not to the holders of power. The next element is verification discipline. In the current conditions, it is necessary to conduct multi-layered verification not only from the media, but we as the audience of the mass media are also required to verify. Because if this element is not carried out it will be very close to the hoax news which results in confusion of information.

Many cases of riots begin from the evidence of the adverse effects of obtaining information without verification. The closest example of this riot that took place in Kandanghaur Indramayu recently. The cause of the public ignited emotions after circulating broadcast-dissemination of information on social media. Misleading information regarding a resident who was killed due to mistreatment by his neighbouring village. Even though his death was caused by a traffic accident. The Information is immediately trusted and chewed by the community is a trigger for social conflict. As a result, hundreds of homes were damaged. Kindship is no longer maintained [3].

The fourth element of journalism is independence. Independent from the object of its coverage. Regarding this fourth element, social media can actually be used as opposed to mainstream media. Because it is driven by personal and community without any desire to gain profits in business. But what is happening now both social media and mainstream media has now been carried away by private interests that are only to benefit certain groups.

As a result of the many hoaxes that circulated in noise in the public sphere. Identification of this noise at least pursed five things. First, the arrogance of the majority who understate minority. The power of the masses is often exhibited for the sake of coercion that usually begins with solicitation and incitement on social media. Second, The rampantionsectarian attitudes. This attitude assumes his believer absolute truthiness. Third, the struggle for political power with leak of ethics. Fourth, the strengthening of media capitalization and last one is weakening of community involvement in voicing public interests. The Fifth Elements of journalism is intended for power monitors. But journalism must become a connector for the oppressed tongue. The mass media should not only be a display case for officials without giving portions to ordinary people. The sixth element is journalism as a public forum. Public place discussion. Furthermore, journalism must make the news relevant to current conditions. Last is conscience. Journalism must be oriented towards conscience.

Media Literacy is the ability to access, analyse, evaluate and create media in a variety of forms [4]. From definition we have to ability when we want to reach many information. Information in any platform. As an audience we just not access, read but we must analyse and evaluate whole information what we get. As we know, literacy media is a way to find the truth in mass media. Our brains depend on information to work optimally. The quality of information we engage with largely determines our perceptions, beliefs and attitudes. It could be information from other persons, the media, libraries, archives, museums, publishers, or other information providers including those on the Internet. People across the world are witnessing a dramatic increase in access to information and communication. While some people are starved for information, others are flooded with print, broadcast and digital content. Media and Information Literacy (MIL) provides answers to the questions that we all ask ourselves at some point. How can we access, search, critically assess, use and contribute content wisely, both online and offline? What are our rights online and offline? What are the ethical issues surrounding the access and use of information? How can we engage with media and ICTs to promote equality, intercultural and interreligious dialogue, peace, freedom of expression and access to information?

Media and Information Literacy (MIL), defined as the ability to access, analyse, and create media, is a prerequisite for citizens to realize their rights to freedom of information and expression. A rights-based approach is pursued to define MIL in general, and Digital Media and Information Literacy (DMIL) in particular. Different projects initiated by DW Akademie are drawn on to show the importance of the aspects of creation and engagement. They illustrate that various stakeholders need to be involved so that citizens can critically access, use, and participate in the flow of information on a broad scale.

Media development supports MIL projects because they help people make their own choices and realize their human rights. To achieve this, MIL projects may include training and skill-oriented workshops. But they need to work on other levels, too, and support structural reforms on behalf of informed and active citizens. If journalism required to uphold these nine principles, social media as mass media what create by either individuals. Cause the commotion of the public sphere today has out of tolerance. Hoaxes, slanders, and expressions of hatred are increasingly out of control. Public 
ethics on social media do not seem not to apply so that people easily attack, judge, or curse with harsh words. As a result, public space is not only noisy, but also full of information garbage. Mounting information rubbish is not everyone aware of the dangers. In The right show, some enjoy it, others benefit from this situation [5].

The end of the rampant waste of information on social media, people tend to see reality based on their own glasses. The reality carried by a group of people is believed and distorts the meaning. Severity of what is believed is then fought for. The logic of public space is also unlogically again. The validity of an aspiration to fight for in the public sphere is no longer based on how strong the basis of the argument is based on, but rather on how strong the mass base that supports it.

To solve all the uproar on social media, its urgent look for how the answer. At least there are five identification problems that cause this pile of garbage information. Firstly cause of fighting for without ethics. Political opponents are considered enemies. All means are carried out so that political opponents lose their mass base. The method used to reach the thirst for power is to attack by slander, fighting sheep and far truthinesstruth. Second, sectarian seeds that sprout. Especially if it is wrapped in tribal, religious and intergroup races. Third, the majority force which nullifies minorities. Because being the majority feels the most right to sit in power [6]. Fourth, the increasingly strong paradigm of capitalism that is ready to cook information rubbish in order to gain sympathy. Fifth, the depletion of people's sensitivity to social phenomena. This led to hedonism and permissiveness in the midst of society. In fact, if the community has been literately educated, it will become the frontline in sorting waste information [7].

\section{CONCLUSION}

The phenomenon which has become pathology cannot be allowed to continue. The government as the organizer of the state should be present to sterilize public space. Sterilization does not mean suppressing medias that is considered often to spread hatred. Because this effort is clearly ineffective. Because the sites indicated hoax spreader if closed will come back with a new face. Literacy education can be done as a first step to provide awareness to the public regarding waste information. Media literacy education also continues to be encouraged by all elements of society. Therefore, the solution by fixing the Divine verses its still can be done. By the notes, the universal messages from religion which include justice, compassion, caring for the environment, mutual respect and the path of peace can still continue to be encouraged to the community. The fight against hoax is also not only by make an adhoc institutions such as the national cyber agency, but rather to building a civil society that can supervise each other every time there is hoax.

In the end, public trust in the mainstream media should not be betrayed because many mainstream media present hoax. Because if see from the idealist of a news story, hoax is not only slanderous news and hate speech. Hoax can also be partisan news, news far from the truth, and news without verification.

\section{REFERENCES}

[1] Majalah Pantau, Edisi Mei hingga Juni, Jakarta, 2002.

[2] B. Kovack and T. Resential, The Elements of Journalism What Newspeople Should Know and The Public Should Expect, New York, 2002.

[3] K. Young, Bunk: The Rise of Hoaxes, Humbug, Plagiarists, Phonies, Post-Facts, and Fake News, Boston, 1997.

[4] A. Harsono, Agama Saya adalah Jurnalisme, Jakarta: Kanisius, 2014

[5] J. Gilbert, The Trayvon Hoax: Unmasking the Witness Fraud that Divided America, California: California Publisher, 2017.

[6] S. Syah, Rambu Rambu Jurnalistik, Surabaya: Pustaka Pelajar, 2008.

[7] L. Menand, Literary Hoaxs and The Etchics of Authorship, New York, 2018 . 